\title{
Culture Genesis of the Peoples of the North of the Yenisei. Interaction of Cultures (on the Basis of the Materials of Krasnoyarsk Regional Local Lore Museum)
}

\author{
Mikhail S. Batasheva and Nicolay P. Makarov ${ }^{\mathrm{a}, \mathrm{b} *}$ \\ ${ }^{a}$ Krasnoyarsk Regional Local Lore Museum \\ 84 Dubrovinskogo Str., Krasnoyarsk, 660049, Russia \\ ${ }^{b}$ Siberian Federal University \\ 79 Svobodny, Krasnoyarsk, 660041, Russia
}

Received 25.10.2017, received in revised form 14.11.2017, accepted 27.11.2017

\begin{abstract}
One of the aspects of the culture genesis of the peoples of the North of the Krasnoyarsk Territory is studied in the article. Mutual influence of the indigenous peoples of the North of Central Siberia and the Russian population in the field of material and spiritual culture is described. Christianization of the aboriginal population adjoins the penetration of shamanism into the beliefs of Russians. Dolgans and Kets borrow new types of transport and dwellings from Russians. The autochthonous population transmits to the Russian superethnos its methods of management and clothing, borrowing, in turn, items of industrial production and food products. Tobacco smoking and alcohol are becoming widely spread. Detached dwelling of aboriginal peoples leads to the borrowing of funeral rites, household items and decorations, hunting and fishing methods, as well as reindeer herding from neighbors.
\end{abstract}

Keywords: the Krasnoyarsk Territory, north, autochthonous peoples, Russians, mutual influence, culture, traditions, innovations.

The reported study was funded by Russian Foundation for Basic Research, Government of the Krasnoyarsk Territory, Krasnoyarsk Region Science and Technology Support Fund within the framework of the research project № 17-11-24603.

DOI: 10.17516/1997-1370-0176.

Research area: culturology.

\section{Introduction}

Despite a significant number of publications, the issue of culture genesis is still understudied. Various aspects of the complex process of culture genesis were considered in the studies of many researchers. E.S. Markaryan (1973) and A.P. Okladnikov (1973) were the pioneers in this field in the USSR. Following them, the issues of culture genesis were studied by V. Alekseev, S. Arutyunov, V. Bochkarev, N. Gumilev, M. Kagan, V. Masson, Yu. Semenov, V. Stepin, A. Flier, etc.

Numerous works by A.P. Okladnikov, who understood culture genesis as the process of emergence and development of cultural complexes in the primitive epoch, were

(C) Siberian Federal University. All rights reserved

* Corresponding author E-mail address: bms@kkkm.ru; mnp@kkkm.ru 
particularly important for the study of the early stages of culture genesis of the ancient Siberian tribes.

Even for this ancient era, innovations in culture were associated not only with its evolution, but with migrations and mutual influence of neighboring tribes. The picture of cultural genesis is even more complicated for the later epochs of the Iron Age and the Middle Ages. At the same time, the attention of the researchers was drawn to the most studied regions of the West (Ocherki kul'turogeneza..., 1994, 1995), Southern and Central Siberia (Savinov, 1994, 2002).

In this regard, the northern territories of the Krasnoyarsk Territory have remained archaeologically understudied for a long time. Only the breakthrough in the accumulation of the sources associated with large-scale works in the Northern Angara region (Korovushkin, 2017) and in the Lower Yenisei regions made it possible to give an overview of the ancient stages of the Krasnoyarsk North's culture genesis (Makarov, 2013).

Turning to the analysis of the history of emergence of the modern indigenous peoples of Central Siberia, the authors proposed their vision of archaeological and ethnographic reconstructions of ethnogenesis of the indigenous peoples of the Krasnoyarsk North (Makarov, Batashev, 2013). Continuing the cycle of publications, the authors of this article aim to reflect the mutual influence of the aboriginal peoples' cultures, both among themselves and with the Russian old-timer population.

\section{Discussion}

The funds of the Krasnoyarsk Regional Museum of Local Lore have accumulated significant materials of numerous expeditions to various areas of the Yenisei Region in the late $19^{\text {th }}-20^{\text {th }}$ centuries. These unpublished materials are the original consequence of the interaction of various peoples of the Yenisei North.
During the $17^{\text {th }}-$ early $20^{\text {th }}$ centuries the influence of Russian culture on the traditional aboriginal cultures of the north of Central Siberia manifested itself, first of all, in various spheres of life and production of the indigenous population. Flour, tea, tobacco and alcohol became customary products already in the $18^{\text {th }}$ century. By the $20^{\text {th }}$ century, according to the materials of the Circumpolar Census of 19261927, such products as rye and wheat flour, ringshaped cracknel, bagels, rusks, butter, pekoe and brick tea, sugar, snuff and leaf tobacco, makhorka, vodka, alcohol and, to a lesser extent, salt became a part of their diet. Not all families, of course, could afford to purchase this set of products, but for the families of wealthy reindeer herders it was a matter of course. But even not very rich representatives of the indigenous population tried not to deprive themselves of an opportunity to purchase quite expensive and prestigious food products. A statement of one Evenk, quoted by N.V. Sushilin, a copyist of the Circumpolar Census, is indicative in this respect. He writes: "None of them (the Evenkis-authors) never know their duty (that is, its amount, and are not interested in it) and expect everything to be given to them everything in the first instance: oil, beads, cloth and other luxuries (moreover, only of the highest quality) and they never count on whether they have enough money or not, and how they will pay off their debts. "But my eyes are my owner, not my pocket. If the god is rich (i.e. a rich harvest of squirrels' coats) than we will have to pay off (repay) the debt, and if there is no squirrel - than Rusa (i.e. Russian) should feed the Avanki (the Evenkis)" (Materialy obsledovaniia..., 22). This statement evidently signifies a demand (or, rather, an already formed habit) for a paternalistic attitude to the natives from the Russian population and the authorities. Since the middle of the $19^{\text {th }}$ century this situation was facilitated by the development of private 
entrepreneurship, and later, the emergence of cooperative organizations, both private and public. Both private traders (the so-called "Tungusniki (fur buyers)" on the Angara) and the cooperators aimed to draw industrialists, attracting them with a variety of goods and large loans provision.

Along with food products, the industrial goods: beads, buttons, cloth and wool were also in great demand among the aborigines. New dishes from previously unknown materials displaced, in some extend, traditional utensils made of wood, birch bark and leather - copper and cast iron boilers, kettles, glass and even porcelain dishes became widely distributed. The peoples of the north of our region had spoons that were previously virtually unknown to them, since in their cultures there was no tradition of using broths for food. All these subjects are widely represented in the KRMLL funds.

The tradition of tobacco smoking became of great importance in Aboriginal cultures. And along with it its additional merchandise - pipes, pouches, snuffboxes and picks for cleaning the head of the pipe and the channel connecting the head to the shank. Pipes of all types known in Siberia were widely spread in the territory of the Yenisei region. The funds of the KRMLL have the pipes of the Enets, Nenets, Nganasans (Russian type), Kets and Selkups (Russian and Bokharan types), Evenkis (Russian, American and Bokharan types), Dolgans (Russian, American and Chinese types) and Tuvinians (Chinese type) (Shapovalov, 2002). There were also surrogates for smoking - bracket fungus which was mixed into the tobacco by the Kets and tobacco from tobacco dust and birch sawdust. Such a mixture was smoked by the Selkups when there was no traditional tobacco.

The repeatedly increased need for the hunting for fur-bearing animals, with an aim of paying yasak, led to borrowing of a lot of self- made tools for animals hunting from Russian industrialists. Puncheons, sable traps, rat traps, breams and traps are among them. In the fishing industry, mainly in the lower reaches of the Yenisei river, seines became widely spread, especially from the middle of the $19^{\text {th }}$ century, when commercial fishing started its rapid development in this region. Even the material from which the local indigenous population made the traditional nets - pushchalni was replaced. Instead of plant fibers and veins they started using horse hair and sackcloth.

From the Russians the Kets mastered the construction of large boats or boats that could sail and had a kind of cabin on board that allowed them to shelter in it during bad weather and at night (Fig. 1). The Ket families spent the whole summer on the Yenisei river in such boats (Alekseenko, 1961).

Another means of transportation, borrowed from the Russians, in this case, by the Dolgans, is the so-called sledge chum - balok (Fig. 2). It was a small house made of thin beams, covered with skins and canvas cloth and mounted on skids. Flat plain landscape allowed them to move in such a rather bulky dwelling in Taimyr tundra. Moreover, the Dolgans themselves were not able to make beams and bought them from Russians (Popov, 1952). KRMLL funds have both the originals of the most of these tools, as well as models of the aforementioned vehicles.

The number of production tools increased as well. Local population started using new woodworking tools - pointed drills, axes and saws. At the same time, smithcraft that was widely spread even before the arrival of the Russians had gradually degraded by the end of the $19^{\text {th }}$ century. Purchase of iron played its role both in products and in scrap.

An integral part of the ethnic cultures of all the peoples of our region was the extensive use of firearms. Along with that new hunter's 


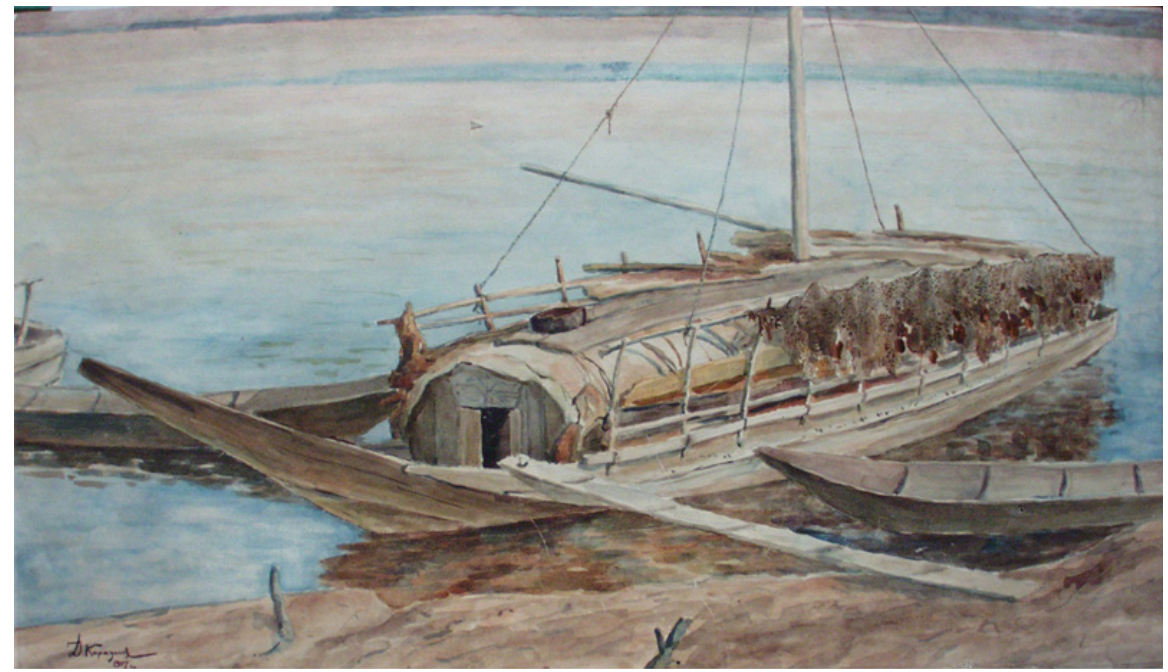

Fig. 1. Boat ilimka. Painting by D. Karatanov, 1907

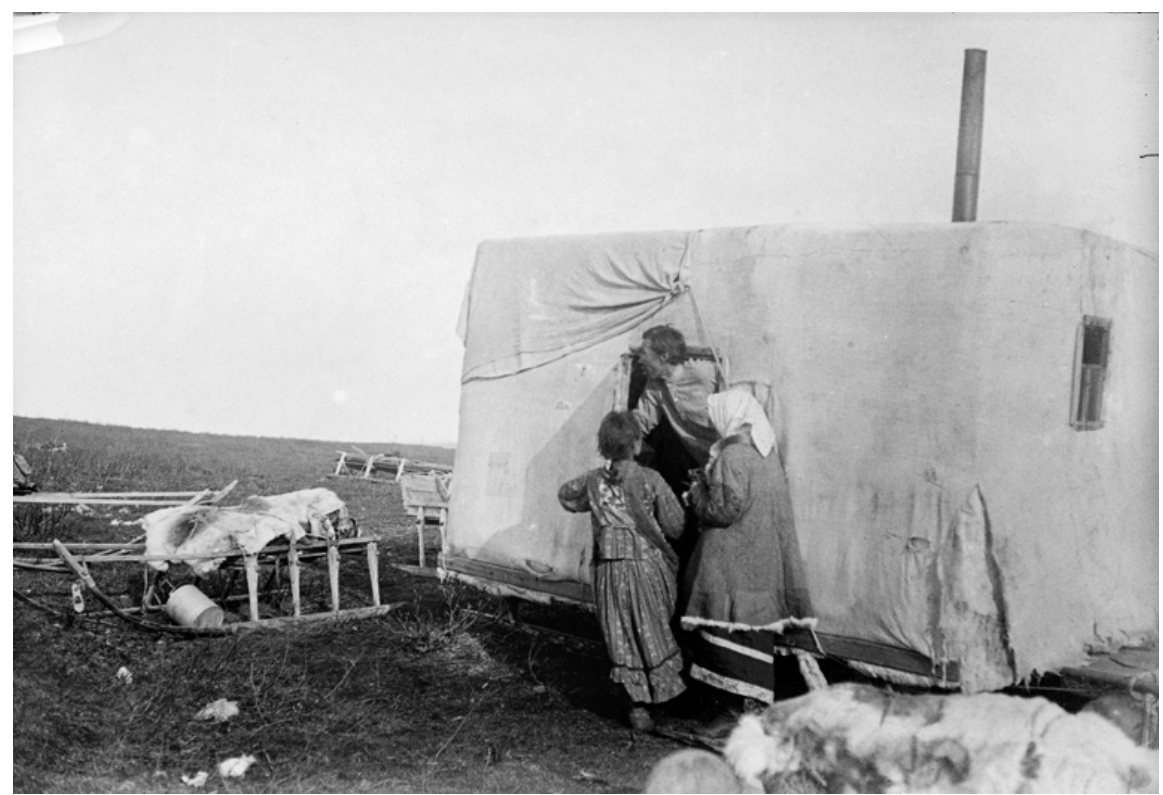

Fig. 2. Dolgan's balok. P. Tyurin. 1926. Funds of the Krasnoyarsk Museum

ammunition appeared: the so-called natruska that consisted of a shoulder belt, to which a charger for gunpowder was attached, a powder flask, a bag for bullets, a capsule, a resin pocket and a screwdriver. Self-made bullet molds, shot molds, and loading tubes were also produced. These objects were made of wood, metal, birch bark and stone. All of them are also widely represented in the funds of our museum.
Christianization of the indigenous population of Siberia started only from the early $18^{\text {th }}$ century. And this process was rather uneven. The periods of active missionary activity were followed by the periods of stagnation in this activity. Therefore, even in the early $20^{\text {th }}$ century there were significant groups of pagans, especially among the Nganasans and the Nenets. In addition, Christianization was of rather superficial nature. 


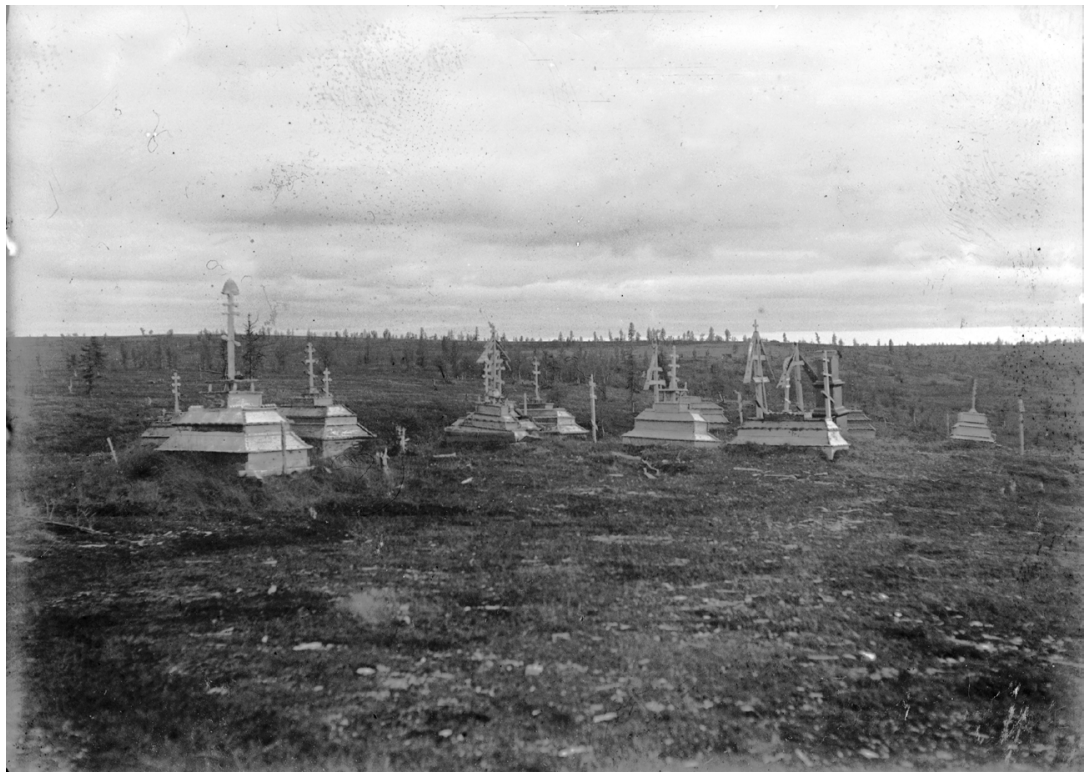

Fig. 3. Dolgans cemetery. I.I. Baluev. 1938. Funds of the Krasnoyarsk Museum

In fact, the newly converted Christians were content only with the act of baptism, and several times a year, if they were lucky, visited a temple or a priest, for the purpose of baptism, wedding and funeral service. Christian features were most noticeably manifested in the styles of graves and funeral rites. Thus, by the early $20^{\text {th }}$ century burials in land and air almost everywhere, except for Taimyr, were replaced by inhumation of the deceased. Relapses took place only in cases of burials of shamans and infants.

Some peoples (Dolgans and Selkups) started having permanent cemeteries (Fig. 3). The funds of the KRMLL contain accompanying material from more than a dozen burials of the Ents, the Nganasans and the Evenkis (coll. E No. 1535, $1572,1643,1659)$. It is mostly represented by the items of Russian origin - copper, brass and bronze pendants, tools of trade and everyday life items.

At the same time, syncretism of the local forms of worship and Orthodoxy is noticeable as well (transfer of the local forms of worship to Orthodox shrines). A clear example of this is collection E No. 1622, which was received by the museum funds in 1926 from a well-known ethnographer and a major Soviet figure in the Sovietization of the Yenisei North I.M. Suslov. This collection contains things from the grave of the locally revered Saint Pimen, located in the Tolsty Nos settlement in the lower reaches of the Yenisei. Representatives of the local peoples - the Nenets, the Enets and the Dolgans have clearly transferred their ideas about the sacred places and their veneration to this grave. When this shrine was liquidated the following items were collected and then transferred to the museum: white corporal with two black crosses sewn onto it, an icon of the Mother of God (heavily covered with lampblack), a copper cast icon of St. Nicholas the Wonderworker, paws and skins of arctic foxes and foxes, a pebble on a beaded belt, reindeer wool tied in a piece of red cloth and a cast bronze pendant on a chain with the image of a kneeling dwarf with a glass in his hand. In addition to it, a large number of old coins were collected (Inventory Book 3).

Carved Orthodox calendars, the so-called paschal cycles appeared in the Dolgan, Evenki and Yakut cultures (Konstantinov, 1961). They 


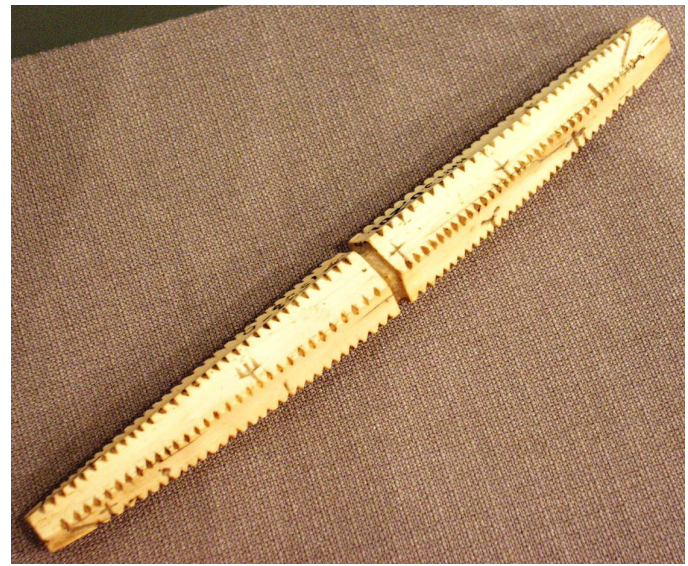

Fig. 4. Paschal cycle calendar. The Evenkis. Funds of the Krasnoyarsk Museum

appeared in the Russian Pomorye, but by the $19^{\text {th }}$ century became an integral part of everyday life of the Orthodox part of local peoples. The Krasnoyarsk museum has ten such calendars. Two of them are carved from the mammoth's tusk, the rest are wooden (Fig. 4).

Some games, such as draughts and playing cards became widely spread among the local population. But they had their own specific features reflecting reality familiar to the aborigines. Thus, for example, in the Enets selfmade draughts the board was called kotaraide, the white squares were tude (lake), the black ones - dia (land), the pieces - ne (women) and khaza (men). King - lode, to lock up - fendibago (literally: prison guard) (coll. 1572/65) (Fig. 5).

The role and influence of the Russian administrative system on the socio-economic and potestary connections of the traditional society of the peoples of Siberia deserves a separate study. For this issue three artifacts from coll. E No. 1659, received by the museum funds as the results of the Northern Expedition of the Krasnoyarsk Regional Museum in 1938-1939 led by B.O. Dolgikh are of interest. These items are a cloth caftan, a scarlet hat and a sash made of blue silk with golden fringe and lining. These

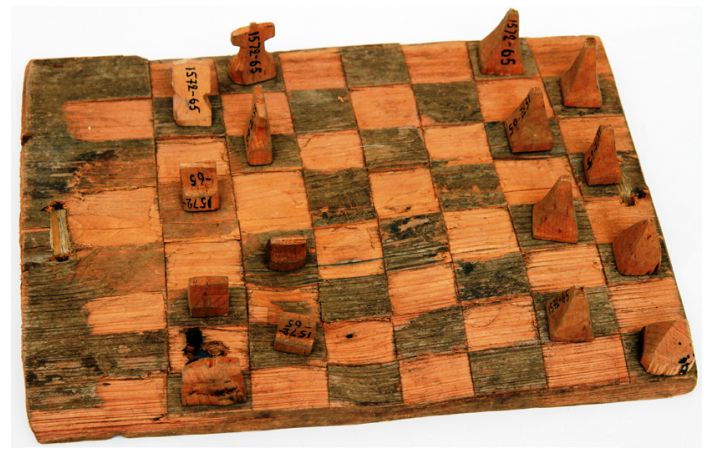

Fig. 5. Draughts. The Enets. Funds of the Krasnoyarsk Museum

items are clearly prestigious and their history is interesting. In 1837 the Turukhansk separate assessor Kushchevsky solicited for the rewarding of Oko with a red caftan for donating 100 reindeer (50 bulls and 50 does) to the Treasury to deliver bread to Zatundrinsky's shops. A certificate of rewarding Oko with the caftan and the sash ("with the permission of His Imperial Majesty") was signed by the Yenisei Civil Governor V.A. Kopylov on August 3, 1839 (Archives of the KRMLL, No. 7886/216). The high status value of these items is indicated by the fact that they were kept by Oko family for 100 years. B.O. Dolgikh also received the items and the documents (the solicitation and the Letter of Recognition) from Oko's great-grandson Arti Yarotsky (Items of the Department of Aboriginal Ethnography of the KRMLL).

The authority of individual representatives of the aboriginal population was also facilitated by their inclusion in the structure of the lower stratum of the administrative structures of the Russian state - the appointment of tribal elders of foreign municipal councils and volosts. A visible sign of the "high" position of such a person was a copper seal or a breastplate given to him. One of such stamps was received by the KRMLL in 1940. The inscription on it indicates that it belonged to 
a tribal sergeant of the 3rd Summer Tunguska Municipal Council (Chekaninsky, 1914).

If there are many examples of the influence of Russian culture on the aboriginal population, the evidence of the reverse influence did not often attract the researchers' attention. But in the course of various Museum expeditions a lot of such facts were recorded.

In 1911 the funds of the Krasnoyarsk Museum received a large collection of everyday life items of the Angara peasants (coll. E No. 1544). It is interesting that among 423 items of this collection, a large part of it (about 60 items) is of Tungus origin. Moreover, we focus attention on the fact that the collection was gathered only in Russian villages, and among the Russian population. This indicates that the items of Tungus origin were widely used in the everyday life of the old-timer population of the Lower Angara region. At the same time, it should be noted that after 1895 the Tungus stopped coming to the Angara, leaving the basin of this river forever and heading north to the Podkamennaya Tunguska. And the items of their life continued to be used in the Russian environment. The collector of this collection A.P. Ermolaev noted in his report: "The closeness of the Tungus is mostly felt in Yarkino, a half of the population wears Tungus clothes, they wear parkas, kokoldas, hats, mukluks and ferrets" (Ermolaev, Kratkii otchet...).

Hereafter we will provide a complete list of the Evenkis items of the collection E No. 1544. The largest number of Tungus items was collected in the village of Yarkino, which was located far from the Angara, in the immediate neighborhood to the Tunguska nomads. A beaded belt from powder flask, a sheath, a needlecase, a cap pouch and a measuring tape, three tinderboxes, a hand vise and a key to them, a bone comb, men's pipes, another a cap pouch and a powder flask, another measuring tape made of bone and horns, a resin pocket, a beaded bag, a powder flask with a measuring rod, a handbag for bullets and a screwdriver, a kibas, knee pads, winter mittens, a ski pole, a kumalan, a winter parka, women's summer mukluks, a reindeer bridle and materials for mukluks were received from the residents of Yarkino.

The items of the Tungus everyday life, especially clothes, were widely spread among the dwellers of Kezhma. In Kezhma the collection was replenished with a beaded belt, a hat, a lasso, a tobacco mortar, a copper women's pipe, knee pads, summer mittens, women's trousers, women's mukluks, a belt decorated with plates, a reindeer saddle made of wood, a kumalan, a woman's breastplate, a women's parka and bakaris.

Separate Tunguska items were completed in the village of Aleshkino (a fox trap), in Aksenovo (a hat), in Boguchany (a spoon, reindeer veins and a resin pocket), in Chadobets (men's pipes, children's parka, a leather bag and a kumalan), in Yarky (a reindeer saddle made of bone) and Yurokta (a hat). Naguzniki, summer mukluks, as well as a parka and a breastplate were purchased in the village of Sokolovo.

As can be seen from the list above, the items related to hunting and fishing and, of course, clothes perfectly adapted to the local climatic conditions, were especially popular among Russians. As for kumalans (fur rugs), the collector noted that they were the articles of merchandise between the Tungus and the Russian peasants, "who use them as rugs to cover the chests".

Some items were used by Russians, apparently, as entertaining trinkets or exotic gizmos. Thus, collection E No. 1547 contains a mold for casting jewelry for the Tungus clothes from the village of Chadobets, a tip of an arrow for an arbalest from the village of Yarki, a shaman's beater and an arkalan from the village of Selengino. An arkalan is a metal pendant, which is attached to the back of the shaman's 
parka between the shoulder blades, is of particular interest (Fig. 6). It is forged with great artistic skill. It is a slightly arcuate plate, to which, on different lengths of chains, eight suspensions are attached. Three of them are made in the form of a deer, two - in the form of a bird of prey's legs, one - in the form of moon and one is a hook on which the baby cradle is suspended. The least suspension in a stylized form shows a zoomorphic image. In the village of Chadobets, the local merchant Vladimirov had “... a good collection of stones, as well as copper, bronze and iron ... iron items - the accessories for shamanism, taken in the taiga along the Chuna river" (Ermolaev, Otchet o poezdke...). Unfortunately it was not possible to purchase the items for the museum, but collector Ermolaev took their photographs, which show that they were pendants from the shaman's costume which, apparently, hung at the shaman's grave.

In the E collection No. 1628 there is a children's Nenets sokuy (for a 9-10-year-old boy).

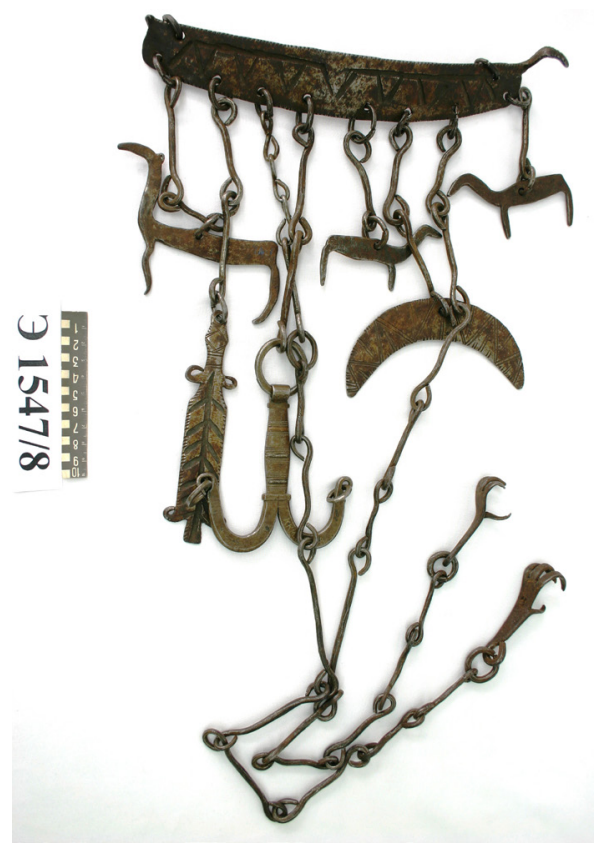

Fig. 6. Arkalan. The Evenks. Funds of the Krasnoyarsk Museum
In the inventory book it is specially stipulated that it was used by the Russian population of the Nosok village in the lower reaches of the Yenisei (Inventory Book 3).

An interesting exhibit item was delivered by M.L. Sher from the Berezovaya village on the river Chuna in 1907. It was a wooden image of a horse wrapped with a horsetail, and, according to the collector, it was an object of worship for the peasants of this village (E col. No.1533/1, inventory book 2) (Fig. 7). Seems like a kind of paganism. In 1914, I.A. Chekaninskii visited the Chuna region for ethnographic purposes. In particular, he tried to find out the details of the cult of a horse from the local population. As a result of numerous surveys, Chekaninskii determined that there was no cult. A horse figure was kept by a local, already Russian, peasant and belonged to his grandfather - a Tungus shaman. At the same time, the researcher pointed out a fearful attitude of the Russian population towards the shamanic cult objects and the Tungus graves, fearing revenge of the dead. Such sentiments dominated everywhere and were based on numerous stories about such cases. Most likely, this phenomenon is due to the fact that a significant number of the local Russified Tungus has settled in the Chuna villages, and some of their traditional ideas have been perceived by their Russian neighbours. Chekaninskii even mentions an instance when a Russian from the village Bedoba on the Irkineeva

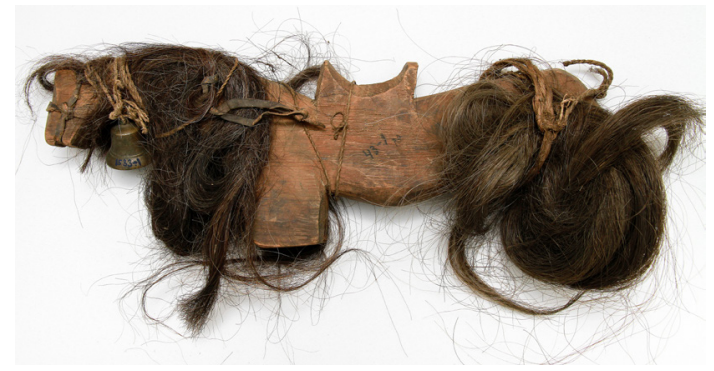

Fig. 7. Image of a horse. Funds of the Krasnoyarsk Museum 
River, a right tributary stream of the Angara River, was a Shaman (Chekaninskii, 1914).

Evidence of shamanism among part of the Russian population was also noted by the director of the Krasnoyarsk Museum A.Ia. Tugarinov during his wintering in Turukhansk in 1917 (Iavorsky, 2011).

Special attention should also be drawn to a study of those groups of the Russian population that have almost completely lost their national specifics and ethnic self-consciousness having become an integral part of the aboriginal environment. In the territory of our region, it refers to the so-called Zatundra (meaning "beyond the tundra") peasants who formed the Lower-Zatundra Peasant Society known since the beginning of the $19^{\text {th }}$ century. According to the population census of 1926-1927 there were 452 members of this society, which made about $12 \%$ of the Dolgans at that time (Dolgikh, 1963). Original Russians, who, by force of circumstances, had been settling in the South Taimyr tundra since the end of the $17^{\text {th }}$ century, were completely Dolganized in the late $19^{\text {th }}-$ early $20^{\text {th }}$ centuries. If in the linguistic, household and production terms their assimilation by the Dolgans was complete, then, on their part, the "peasants" introduced Orthodoxy into the common Dolgan environment. And to this day, the Dolgans are considered to be the most Orthodox people among the indigenous peoples of the Krasnoyarsk North. Although, it should be noted that Christianity of the Dolgans was rather syncretistic, peacefully coexisting with their traditional shamanistic ideas. The fact that shamans could be met even among the descendants of the Zatundra peasants speaks in favour of this. So, in 1930 a famous writer M.I. Osharov gave the Krasnoyarsk Museum a complete shamanic set consisting of a parka, a breastplate, shoes, a tambourine, two mauls, a tambourine case, a copper chain with three bells and a bag for shamanic items. All these items belonged to a shaman of the Zatundra peasants A.A. Aksenov (Chichak) who lived in the Barkhatovo village (E col. No.1635/7-15, Inventory of the department of native ethnography, 1931-1941) (Fig. 8).

Other cult objects of the Zatundra peasants associated with traditional ideas of the local indigenous population are in the E collection No.
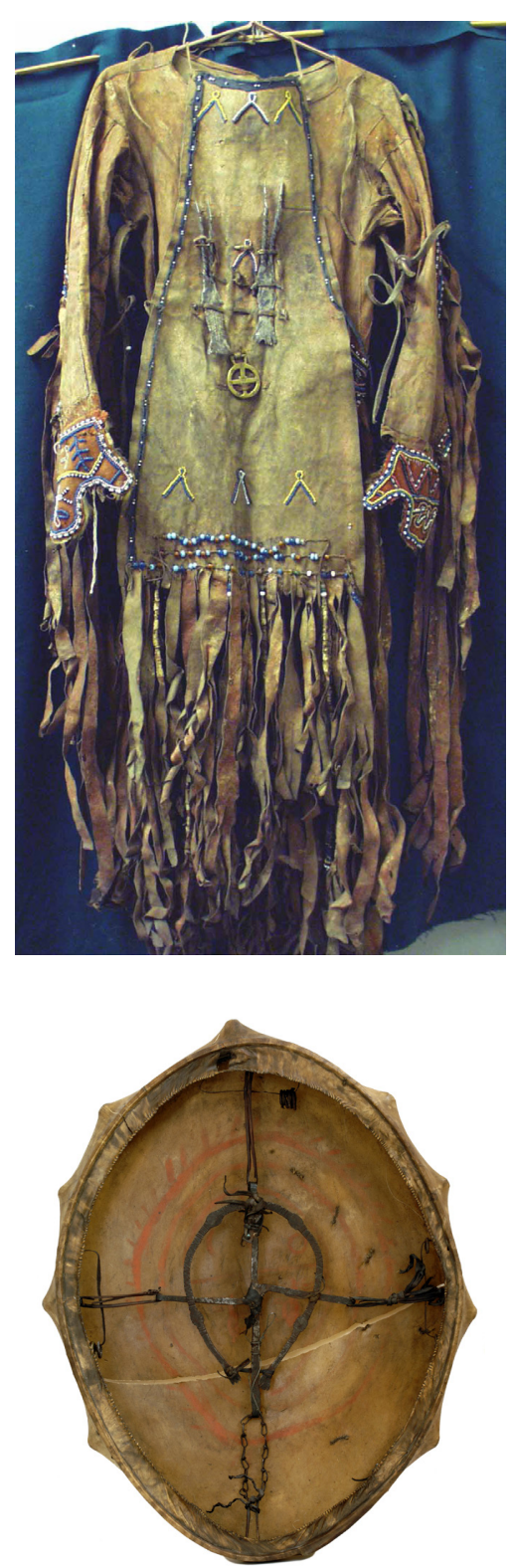

Fig. 8. A.A. Aksenov's shaman costume and tambourine. Funds of the Krasnoyarsk Museum 
1643. These are three wooden figures - one is anthropomorphic, the other - in the form of a deer and the third one depicts a fish. The author of the collection B.O. Dolgikh describes them as follows: "An idol is a wooden image of a female "devil" with a tail. It helps to "exile" illness from a sick person. Illness is manifested by... a wooden figure of a deer without horns. It is given to the "devil" to leave this person riding on it... A wooden figure of a fish is given to the "devil" as provender for the road so that it could leave the sick person ( $\mathrm{E}$ col. No.1643/2-4: Inventory of the department of native ethnography, 1931-1941) (Fig. 9).

All these items have been found in an old barn on the Dudypta River between the villages Old Letov'e and Old Barkhatovo. It is noteworthy that there was a cradle and a rim of a tambourine was lying near the barn. Apparently, a ritual of "curing" a little child was held here, which ended up in failure, as evidenced by the abandoned cradle.

Let us also consider the materials of the Krasnoyarsk Regional Museum of Local

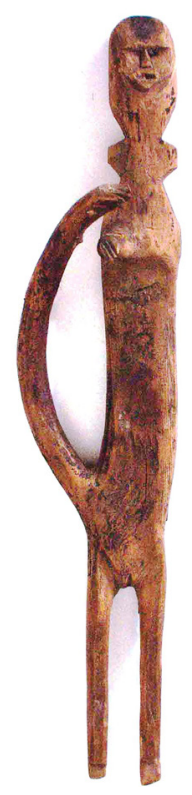

Fig. 9. "Devil" idol. Dolgans. Funds of the Krasnoyarsk Museum
Lore that testify to the mutual influence of the aboriginal peoples on each other. This influence has been known for a long time.

Examples of such borrowings are, as a rule, the distribution of the Yakut belts from the Dolgans, Ket and Yakut bows from the Nganasans and Dolgans, Yakut and Ostyak (i.e. Ket and Selkup) boats throughout Taimyr. It is wellknown about the transition to wearing winter Nenets clothes by their immediate neighbours the Taz Selkups, the Northern Kets, the Enets, the Bolshekhet and the Upper Turukhansk Evenks. The Northern Selkups and Kets borrowed reindeer herding from the Enets and the Nenets. In short, there are many such examples.

The E collection No. 1591 collected from the Selkups of the upper Ket in 1920 includes several items that they adapted from their neighbours - the Ket and the Sym Evenks. It is a cover from a gun and a pair of leather trousers tied to a belt, about which it is directly said that they were borrowed from the Tungus. Then two pairs of different kinds of shoes (kuelei-pevy and kuelei-pevy-kungassy) and a breastplate (kueleimesset). The names of these items confirm their Tungus origin (kuele - tungus). Moreover, the accompanying documents say that these items have become so familiar to the Selkups that they already produce them by themselves (Inventory of the department..., 1931-1941: 16-17).

In the same collection there is a shaman costume of the Selkup Trofim Belozerov (Fig. 10). It is made in the traditional Selkup manner and is decorated with a large number of iron pendants. It is known that all these pendants were forged by a Tungus Stepan Ivigin from Chemba (Inventory Book 3). Thus, this costume is characterized by two ethnic traditions - Selkup and Evenk.

There are two more interesting shamanic sets in the E collection No. 1635. One of them is represented by a parka, a breastplate, shoes, a tambourine, a beater, a tambourine case, a chain 


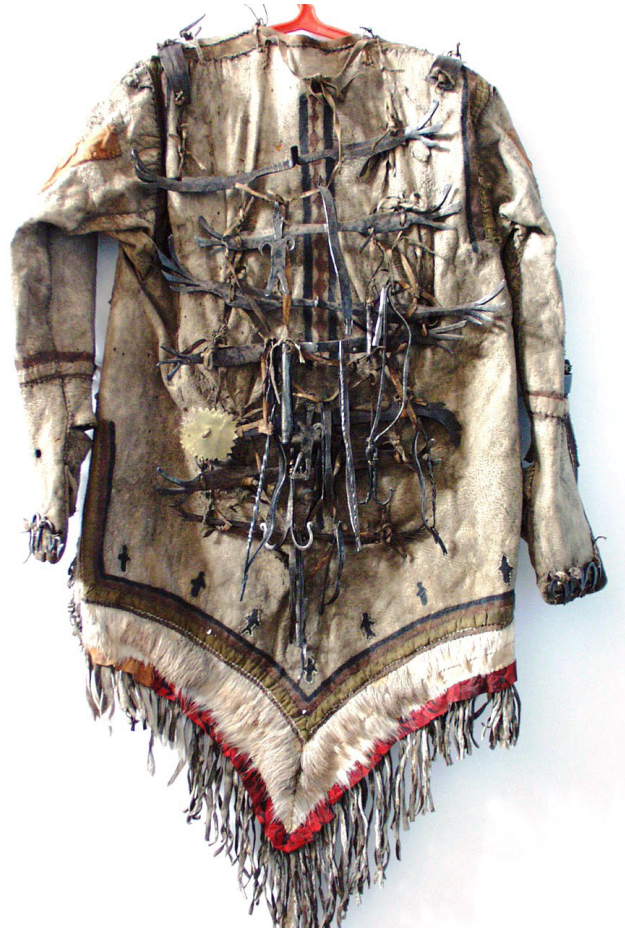

Fig. 10. T. Belozerov's shaman costume. Selkups. Funds of the Krasnoyarsk Museum

with 3 ends and bells, skins of loons and birds of prey. These things belonged to a shaman of the Dolganized Evenks. Another set includes parka, shoes, a headdress, a tambourine, three beaters, a binder with 3 bells, wooden figures of a deer and a predator, a skin of a weasel and skins from a wolf's and a bear's head. This set belonged to a shaman of the Dolganized Zatundra Yakuts (Inventory of the department..., 1931-1941: 103108). These sets perfectly show what a complex, and more precisely, syncretic character had the establishing culture of the new ethnic group of the Dolgans.

The paraphernalia of the Nganasan shaman Kheripte Yarotskii, acquired for the Krasnoyarsk Museum by a famous ethnographer B.O. Dolgikh in 1939, is even more significative in terms of the synthesis of neighbouring ethnic cultures (E collection No. 1659/12-18) (Fig. 11). It consisted of a parka, a breastplate, a headdress, bakari, a tambourine and two beaters. At the same time, the collector indicated that Kheripte shamanized in the Evenki language and one beater is intended for the Tungus (Evenki) spirits, and another onefor the Samoyed (Nganasan) spirits (Inventory of the department..., 1931-1941: 137-139).

It is known that Kheripte's great-grandfather, the above-mentioned Oko Iarotskii who lived in the middle of the $19^{\text {th }}$ century was a "Dolgan", i.e. a Tungus, who married a Nganasan woman and became a wanderer together with his wife's relatives. Apparently, his native language was Evenki. But his children grew up as the typical $100 \%$ Nganasans. Despite this, Kheripte himself, Nganasan in the third generation, performed shamanistic rituals in the Evenki language that was completely incomprehensible to his relatives, and, most likely, to himself. We do not know if Oko was a shaman or a shamanic gift was passed to Kheripte through the female line, for example, from a mother or grandmother who could be Evenk. Be it as it may, the Nganasans' shamanic gift was passed only by inheritance, and therefore the future shaman Kheripte could master the Evenki shamanism only within his family. And apparently, in this family the shamanic succession came from the Evenki shamans. That is why among the spiritual patrons of the Nganasan Kheripte, along with the Samoyed spirits, there also were the Tungus ones.

A similar monument is the burial of a female shaman that was located on the bank of the Dudypta River, $1 \mathrm{~km}$ above the Letov'e trading station (E collection No. 1659/36-49). The author of the collection of objects from this burial, which became the property of the museum in 1939, B.O. Dolgikh attributed it to the period between 1928 and 1934. The burial was in an area of the Dolgan ethnos that had been developing here from the $18^{\text {th }}$ century and the first half of the $19^{\text {th }}$ century (Dolgikh, 1963). Both in the inventory books of the Krasnoyarsk Museum from the 1930's and in the modern inventory 


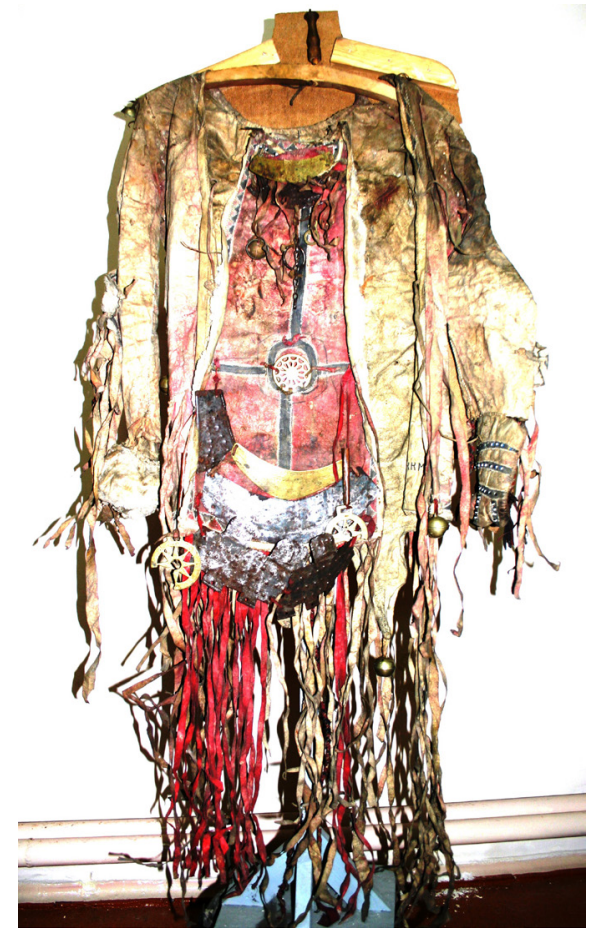

Fig. 11. Kheripte Iarotskii's shaman costume. The Nganasans. Funds of the Krasnoyarsk Museum

book, the items from this burial are attributed to the Dolgans (Inventory of the department..., 1931-1941: 137-139).

However, it is necessary to take into account several factors here. Firstly, one cannot speak of the fully formed Dolgan ethnos by the $30^{\text {ss }}$ of the $20^{\text {th }}$ century yet. Secondly, the shaman belonged to the Evenks that apparently did not fully adapt by the Dolgans. In addition, she was the wife of the former headman of the Zatundra peasant society, Fyodor Petrovich Durakov. And the Durakovs, as is well-know, were the descendants of the Russian servicemen of the Yakut district in the $17^{\text {th }}$ century and their Dolganization began only in the late $19^{\text {th }}$ - early $20^{\text {th }}$ centuries (Dolgikh, 1963).

Within the framework of the given topic this burial is interesting for its design features. The grave was a wooden log construction. The body of the shaman was placed in a log on the surface of the earth, and her shamanistic accessories, including a tambourine, were on the log. The cargo-carrying sled with the personal belongings was located next to the log (Inventory of the department..., 1931-1941: 45-46).

As is known, burial on a tree or in a $\log$ on a platform prevailed among the Evenks. It is similar to the method of burial of the Severobaikalsk Evenks who laid a deceased one in a wooden box and erected a quadrangular $\log$ frame over it. Clothes and other things were hanged nearby on trees (Vasilevich, 1969: 241). A wooden log over an earth grave, over which a gable roof was built, was widely distributed among the Yakuts in the $18^{\text {th }}$ and the first half of the $19^{\text {th }}$ centuries. The Yakuts of Anabar and Olenek and the eastern Dolgans had a wooden tombstone made of logs stocked over the grave (D'iachenko, 2009). Sledges left at the grave were cut along in half and installed on both sides of the burial.

Thus, the peculiarities of this burial that distinguish it from the general context of the Dolgan burials include the placement of a corpse in a log, but on the surface of the earth, without inhumation. The absence of a gable roof. Sledges are not sawn up. The location of shamanistic supplies are on a log, and not near.

The above-mentioned materials are only a small part of the cultural heritage of the peoples of the Krasnoyarsk North carefully stored in the funds of the Krasnoyarsk Regional Museum of Local Lore waiting for its researchers.

\section{Conclusion}

Summarizing the above said, let us make the following conclusions. In the complex process of cultural genesis of the peoples of the Yenisei North, the mutual influence of cultures of neighbouring ethnic groups is one of the main aspects. Collections of the Krasnoyarsk Regional Museum of Local Lore confirm the significant influence in the $19^{\text {th }}-20^{\text {th }}$ centuries of the Russian 
super-ethnos culture on the spiritual and material culture of the indigenous small-numbered peoples of the North of the modern Krasnoyarsk Territory. At the same time, certain processes of Christianization of autochthonous peoples were accompanied by the preservation of traditional cults, dual beliefs and even a certain influence of shamanism on a part of the Russian old-timer population.

In the material culture, innovations are also connected with the mutual influence of neighbouring peoples. New types of food, industrial goods, household products and jewellery, transportation, hunting methods of the Russian population with firearms and dead falls for fur animals become common for Siberian ethnoses. On the other hand, Russians increasingly use sensible clothes of aborigines in places where Evenks and other peoples live.
Finally, along with the assimilation of autochthonous peoples by the Russians, there were also reverse processes, for example, the complete absorption of the Russian Zatundra peasants by the forming Dolgan ethnos.

Less noticeable, but repeatedly noted in the description of the museum's collections, is the mutual influence of the autochthonous groups on each other. It is the Selkups' and Kets' borrowing of reindeer breeding from the neighbours and wearing winter clothes from the Nenets. Yakut belts are widely distributed among the Dolgans. The Ket bows are highly valued by all the neighbours, as well as the Ket and Selkup boats in Taimyr.

Thus, museum collections represent an important source in the reconstruction of various aspects of the cultural genesis of the peoples of the Yenisei North in a rapidly changing modern technogenic culture.

\section{References}

Alekseenko, E.A. (1961). Sredstva peredvizheniia ketov [Means of transportation of the Kets]. In Sibirskii etnograficheskii sbornik [Siberian ethnographic collection]. 3. M-L: Publishing House of the USSR Akademy of Sciences, 64-97.

Chekaninskii, I. (1914). Sledy shamanskogo kul'ta v russko-tungusskikh poseleniiakh po reke Chune v Eniseiskoi gubernii [Traces of a shamanic cult in Russian-Tungus settlements along the Chuna River in the Yenisei province]. In Etnograficheskoe obozrenie [Ethnographic Review], (3-4).

Dolgikh, B.O. (1963). Proiskhozhdenie dolgan [The origin of the Dolgans]. In Sibirskii etnograficheskii sbornik [Siberian ethnographic collection]. 5. M-L: Publishing House of the USSR Akademy of Sciences, 92-41.

D'iachenko, V.I. (2009). Namogil'nye pamiatniki dolgan skvoz' prizmu ikh etnogeneza [Memorial stones of the Dolgans through the prism of their ethnogenesis]. In Sibirskii sbornik-1: Pogrebal'nyi obriad narodov Sibiri i sopredel'nykh territorii [Siberian collection-1: Funeral rite of the peoples of Siberia and adjacent territories]. 2, St. Petersburg: MAE RAS, "Izd-vo "Lema" LLC, 38-44.

Ermolaev, A.P. Kratkii otchet o poezdke v Priangarskii krai v ianvare-aprele 1911 g. [Brief report on a trip to the Angara region in January-April 1911]. Krasnoyarsk Regional Museum of Local Lore 7886 PI, 203.

Ermolaev, A.P. Otchet o poezdke v Priangarskii krai [Report on a trip to the Angara region]. Krasnoyarsk Regional Museum of Local Lore 7886 PI, 209.

Iavorsky, A.L. (2011). Dvadtsat' let na Enisee. Arkadiiu Iakovlevichu posviashchaetsia [Twenty years on the Yenisei. Dedicated to Arkadii Iakovlevich Tugarinov]. In Sbornik nauchnykh statei: 
Krasnoiarskii kraevoi kraevedcheskii muzei [Collection of scientific articles: Krasnoyarsk Regional Museum of Local Lore], 151-360.

Inventory book No. 2 of the Krasnoyarsk City Museum, 1901-1921.

Inventory book on ethnographic collections of the Krasnoyarsk Regional Museum of Local Lore. Book 3.

Inventory of the department of indigenous ethnography, 1931-1941.

Konstantinov, P.A. (1961). Narodnye reznye kalendari [Folk carved calendars]. In Sbornik muzeia arkheologii i etnografii [Collection of the Museum of Archeology and Ethnography], (20), M.-L.: Izdvo AN SSSR, 84-113.

Korovushkin, D.G. (2017). Boguchanskaia arkheologicheskaia ekspeditsiia IAET SO RAN: kratkii istoricheskii ocherk [Boguchansk archaeological expedition of the Institute of Atomic Energy SB RAS: a brief historical essay]. In Severnye arkhivy i ekspeditsii [Northern archives and expeditions]. 06, 2, 23-42.

Makarov, N.P., Batashev, M.S. (2013). Teoriia i praktika arkheologo-etnograficheskikh rekonstruktsii protsessa etnogeneza korennykh narodov Krasnoiarskogo severa [Theory and practice of archaeological and ethnographic reconstructions of the ethnogenesis process of the indigenous peoples of the Krasnoyarsk North]. In Vestnik Tomskogo gosudarstvennogo universiteta [Bulletin of Tomsk State University]. History. Tomsk, 3 (23), 190-193.

Makarov, N.P. (2013). The Ancient stages of the culture genesis of the Krasnoyarsk Indigenous Peoples. In Journal of Siberian University, Humanities, social Sciences 6 (2013 6) 816-841.

Markarian, E.S. (1973). O genezise chelovecheskoi deiatel'nosti i kul'tury [On the genesis of human activity and culture]. Yerevan: Publishing House of the Armenian SSR Academy of Sciences, $147 \mathrm{p}$.

Materials of the survey of the Podkamennaia Tunguska in 1926-1927. Sushilina, N.V. Krasnoyarsk Regional Museum of Local Lore, o/f 7886/PIR 189.

Museum of the Prieniseiskii Krai. Inventory of ethnographic department, 1921-1933.

Ocherki kul'turogeneza narodov Zapadnoi Sibiri [Essays on the culture genesis of the Peoples of Western Siberia], V. 1-4. Tomsk: Publishing house of Tomsk University, 1994-1995.

Okladnikov, A.P. (1973). Etnogenez i kul'turogenez [Ethnogenesis and culture genesis]. In Problemy etnogeneza narodov Sibiri i Dal'nego Vostoka: Tezisy dokladov Vsesoiuznoi konferentsii [Problems of the Ethnogenesis of the Peoples of Siberia and the Far East: Abstracts of the Reports of the All-Union Conference], 1-21 December 1973, Novosibirsk, 11.

Popov, A.A. (1952). Kochevaia zhizn' i tipy zhilishch u dolgan [Nomadic life and types of dwellings among the Dolgans]. In Sibirskii etnograficheskii sbornik [Siberian ethnographic collection]. 1. M-L: Publishing House of the USSR Akademy of Sciences, 142-172.

Savinov, D.G. (1994). Gosudarstva i kul'turogenez na territorii Iuzhnoi Sibiri v epokhu rannego srednevekov'ia [States and culture genesis in the Territory of Southern Siberia in the Early Middle Ages]. Kemerovo: KemSU, 215 p.

Savinov, D.G. (2002). Rannie kochevniki Verkhnego Eniseia. Arkheologicheskie kul'tury $i$ kul'turogenez [Early nomads of the Upper Yenisei. Archaeological cultures and culture genesis]. St. Petersburg: St. Petersburg State University, $204 \mathrm{p}$.

Shapovalov, A.V. (2002). Ocherki istorii i kul'tury potrebleniia tabaka v Sibiri. XVII-pervaia polovina $X X v v$. [Essays on the history and culture of tobacco consumption in Siberia. The $17^{\text {th }}$ - first half of the $20^{\text {th }}$ centuries]. Novosibirsk, publishing center "Progress-servis", $257 \mathrm{p}$. 
Vasilevich, G.M. (1969). Evenki. Istoriko-etnograficheskie ocherki (XVIII - nachalo XX v.) [Evenki. Historical and ethnographic essays (18 th - early 20 th centuries)]. L.: "Nauka", $304 \mathrm{p}$.

\title{
Культурогенез народов Енисейского Севера. Взаимодействие культур (по материалам Красноярского краевого краеведческого музея)
}

\author{
М.С. Баташев ${ }^{\text {, }}$ Н.П. Макаров ${ }^{\text {a, }}$ \\ а Красноярский краевой краеведческий музей, \\ Россия, 660049, Красноярск, ул. Дубровинского, 84 \\ ${ }^{\sigma}$ Сибирский федеральный университет \\ Россия, 660041, Красноярск, пр. Свободный, 79
}

\begin{abstract}
В статье рассматривается один из аспектов культурогенеза народов Севера Красноярского края. Описывается взаимное влияние коренных народов Севера Средней Сибири и русского населения в области материальной и духовной культуры. Христианизация аборигенного населения соседствует с проникновением шаманизма в верования русских. Долгане и кеть заимствуют у русских новые типь транспорта и жилищ.. Автохтонное население передает русскому суперэтносу свои способы хозяйствования, одежду, заимствуя, в свою очередь, предметьл промышленного производства и продукты питания. Распространяется табакокурение и алкоголь. Чересполосное проживание аборигенных народов приводит к заимствованию у соседей погребальных обрядов, бытовых предметов и украшений, способов охоты и рыболовства, а также оленеводства.
\end{abstract}

Ключевые слова: Красноярский край, север, автохтонные народы, русские, взаимовлияние, культура, традициии, новации.

Исследование выполнено при финансовой поддержке Российского фонда фундаментальных исследований, Правительства Красноярского края, Красноярского краевого фонда поддержки научной и научно-технической деятельности в рамках научного проекта № 17-11-24603.

Научная специильность: 24.00.00 - культурология. 